\title{
On Dorian Gray's Two Factors in The Picture of Dorian Gray
}

\author{
LIU Shi-chuan \\ Sichuan University of Arts and Science, Dazhou, China
}

\begin{abstract}
Dorian Gray is a main character in The Picture of Dorian Gray written by Oscar Wilde. As a hero who loves his own unparalleled and beautiful appearance and makes his portrait bear all his sins, Dorian Gray is regarded as a hedonist. However, he can also be regarded as the animal factor of him while his portrait is regarded as the human factor of him. As the animal factor, Dorian Gray degrades deeper and deeper and wants to get rid of the accusations of the portrait under the control of free will all the time, while the portrait, as the human factor, is responsible to bear his sins and control it. This paper shows the human factor and the animal factor and their struggle relationship through the research on the human factor and the animal factor of Dorian Gray.
\end{abstract}

Keywords: Dorian Gray, human factor, animal factor

\section{Introduction}

Dorian Gray is the protagonist in The Picture of Dorian Gray in which the soul of Dorian Gray gets degraded. He is the prototype of the painter Basil Hallward's most favorite portrait because he is not only pure in heart and good in nature, but also so unusually beautiful by birth that what everyone in the world could only read from his face is sincerity and honesty, as if the dirty and evil in life would not be associated with him. Gray had never realized the amazing beauty of his own until one day the painter Basil Hallward created a portrait same as his appearance. In front of the unparalleled portrait of exquisite, Gray realized his own amazing beauty. And induced by hedonism of Lord Henry, Gray sighed that time passed quickly and it was difficult for him to keep youth. So he made a wish which was unlikely to be achieved in the eyes of usual people in front of the picture: He hoped that his face would not be eroded by years forever, and the painting not only should bear the wind and frost of years in his place, but also bear all the desires and sins occurring in his life. Gray actually did do a deal with the devil through his soul. The mad and crazy wish of Gray was realized finally. From then on, he lived in the wild, and scorned low life. He abandoned his lover Sibyl for chasing the ideal of aestheticism, and, in order to cover up the secrets hidden in the picture, killed his friend and benefactor Basil Hallward. He again and again covered up the crimes committed by greater and greater evils, while his face never left any traces of evil. But his process to be psychologically dark, dirty by his own changes, wordless blaming and mocking villainies was recorded by the portrait. Facing the accusations of the portrait, eventually Gray was so unbearable that he took a knife to stab the portrait. However, he fell on the ground and died in pain while the portrait was gaining the youthful appearance.

LIU Shi-chuan, lecturer, M.A., School of Foreign Languages, Sichuan University of Arts and Science. 


\section{Human Factor: The Picture}

The picture of Dorian Gray is a special human factor. In the most of literature, though human factor and animal factor present different combinations and changes and lead to the different characters and personality changes in the literary works, the human factor and the animal factor always could not be observed by the appearance because the human factor and the animal factor are usually combined in a characteristic presenting a hidden sphinx image. But in The Picture of Dorian Gray, the human factor is a different human factor which is not combined in a person with the animal factor. It is individual.

In reality, before Gray saw the portrait same as him, the human factor was not individual but combined in Gray's own body with his animal factor. However, seeing the unparalleled portrait and induced by hedonism of Lord Henry, Gray made a mad wish: He hoped that he could keep his beauty and youth forever and make the picture, instead of him, bear all sins and pains happening in his life. The wish came true unbelievably. Gray would not get old, but he made this deal with the devil so that the human factor of his was abandoned with his own hands and expressed as the picture and gradually lost his own rational will. At the same time, the picture became Gray's human factor.

In fact, human factor is the advanced factor so that it can control the animal factor from the rational will of human beings (NIE, 2011, p. 9). As the human factor, the portrait is not able to control the animal factor of Gray whose strength overweighs its own under the domination of the free will. So the only way to guide and change Gray is to change its own appearance.

The first change of the portrait, happening after Gray's abandoning Sibyl, accused the selfishness and indifference of Gray. Gray loved an actress Sibyl not only for her charming face, dark brown curly hair, but also for her superb performing arts on drama. He had thought that Sibyl was the wife whom he looked for, and she was the same as Juliet and Catherine written by Shakespeare. However, when enjoying in love with Gray, Sibyl thought that all the drama was just affection and she could play well on drama no longer. But Gray did not understand the changes of Sibyl's performing of drama and thought it so mediocre and vulgar that Sybil was the wife whom he had looked for no longer. Though Sibyl cried and explained, Gray still abandoned her. At that time, the picture changed firstly: "The expression looked different. One would have said that there was a torch of cruelty in the mouth" (Wilde, 2014, p. 87). The picture bore all Gray's evil of accusation, indifference to Sybil.

From then on, with the continuous degradation of Gray, the portrait changed again and again. Until the painter Hallward saw his own picture again, the Gray in the picture only had gradually thinning hair and dull eyes, which was an ugly face to the painter. At that time, seeing that face, out of recognition, which recorded all evil of Gray, Hallward knew the truth of Gray's degradation and got shocked, but he still did not give up his rescue of Gray and wanted Gray to repent and turn to the good. Nevertheless, Gray had lost control of the human factor and killed Hallward. The portrait recorded and expressed the criminal process that Gray killed Hallward with the knife: "What was that loathsome red dew that gleamed, wet and glistening, on one of hands, as though the canvas had sweated blood" (Wilde, 2014, p. 167).

The time when Gray took a sword to stab the portrait is also the time when the portrait was the ugliest:

He could see no change, save that in the eyes there was a look of cunning and in the mouth the curved wrinkle of the hypocrite. The thing was still loathsome-more loathsome, if possible, than before-and the scarlet dew that spotted the hand seemed brighter, and more like blood newly spoiled. (Wilde, 2014, p. 216) 
The picture on that time expressed the ugliest time of Gray's soul in his life.

During more than 10 years, the picture recorded the degraded process that Gray was in a life relying on his instincts with no ethics, no distinguishes between the good and the evil, which was same as animals by its own changes. But at the same time, the picture also warned with Gray, and guided and constrained his irrational behavior by its own changes so that eventually Gray's stabbing to the picture was also to kill himself to bear his own moral responsibility. In this way, the human factor, the picture, controls the animal factor, Dorian Gray.

\section{Animal Factor: Gray}

The animal factor is reflected by free will and irrational will, while rational will reflects the human factor. Free will is also known as nature will, mainly produced in animal instinct of human. The main form of expressions of free will is expressed as different desires of human, namely the basic physiological requirements and dynamic in heart, such as sex, appetite, and so on. These desires of human are left by the procedure of the evolution of themselves from animals. As becoming upright and walk to obtain the shape of man by biological selection, human beings also have ethics consciousness to make a difference with animal. However, some instincts of animals like sex are still left. And the irrational will is an immoral will which is not invented by instinct, but from errors in judgment or sinful desires (NIE, 2011, p. 9).

So once losing the human factor, a man will let his body and soul apart for the free will without guidance and constraint. The body without soul will lose the nature of man and become just a man without soul who is completely in a life relying on his instincts, the same as beasts with no ethics and distinguishes (NIE, 2011,p. 10). So does Dorian Gray. When making the mad wish, Gray made the deal with the devil and he also became just the animal factor of a sphinx factor. With the little control of rational will, Gray got more and more degraded and finally walked to the road to destruct under the control of free will and irrational will.

At the time looking at the first change of the picture, Gray recalled his mad wish made in front of the portrait, and found that his mad wish came true. The picture made a birth of all evils of his accusation and indifference to his lover Sibyl which should have been represented on Dorian Gray's own face. At the beginning, he repented what he had done and wrote a letter to Sibyl for apologies. When Lord Henry brought the news of Sybil's death to him and coaxed him through hedonism, Gray started to obey his own instinct. He did not repent for his own behavior any more, but found out all kinds of excuses that the death of Sybil was just a unique ending of a drama in which he had played a role. Though this tragedy was very moving, he was just a spectator. From then on, he became an animal factor controlled by free will and irrational will, and degraded deeper and deeper.

Just because seeing the first stain of the picture, Gray felt that the time had really come for making his choice. Or had his choice already been made? Yes, life has decided that for him—life, and his own infinite curiosity about life. Eternal youth, infinite passion, pleasures subtle and secret, wild joys and wilder sins - he was to have all these things. The portrait was to bear the burden of his shame: that was all. (Wilde, 2014, p. 101)

From then on, as the animal factor was controlled by free will and irrational will, Gray lived in more and more degraded life following his instinct. Gray had adulterous sex, coaxed men and women who loved him to do bad things and made them lose all reputation, was addicted in opium, and did so many bad things. And eventually, Gray even killed his friend, the painter Hallward, calmly called the corpse of Hallward as that thing, and threatened the scientist Campbell to destroy the corpse by chemistry. 
As the animal factor, Gray did countless sins during more than 10 years under the control of free will and irrational will. At the same time, however, the animal factor is not the senior factor in sphinx factor and is enslaved to human factor. So in the end, Gray was beaten by the picture, and stabbed the picture to complete his suicide behavior.

\section{The Struggles Between the Human Factor and the Animal Factor}

Man is a mixture of coexistence of good and evil, that is to say, the human factor and the animal factor both exist in human. Nevertheless, the good and evil can transform to each other side. Evil can develop to the good under the control of human factor; on the contrary, if free from the control of human factor, the good will be the slave of desire. Human wanders between good and evil and plays games between the human factor and the animal factor under the constantly changed energy of free will and rational will. One can commit crimes under the control of animal factor, while he also can save himself by the guidance of human factor (LIU, 2013, p. 24). Though the writer expresses the human factor and the animal factor as two different images: the picture and Gray, there are also continuous struggles between the human factor and the animal factor.

With more and more evils done, the appearance of the picture became more and more ferocious. Gray knew that the picture had witnessed his sins and any one who saw this picture would know all his secrets in his heart. As the human factor, the picture repeatedly warned Gray through its own changes, while Gray, as animal factor following his own instinct, chose to hide the picture in the attic, took the key to the attic with himself, and saw the picture every now and then to ensure that no one found the picture. So what can be found from Gray was just a beautiful and youthful face, and the vestiges of years and evil born by the picture were not found. It seemed that the animal factor beat the human factor. In fact, however, while hiding the picture, Gray also was in fear of the picture. After every evil, looking at increasingly distorted portrait and his own handsome young face in the mirror, Gray was still stimulated by the great contrast. Even though doing something bad, Gray did not worry about the blame and punishments from the society, and the only fear of him was the portrait because it was his own conscience.

Sometimes facing to the warnings of the picture, Gray also constantly wanted to save himself, which is the reflection that the human factor has held the dominant position several times. But the human factor did not gain the success to make Gray develop to the good and animal factor hold the dominant position for a long time because of the weak strength of the human factor. Gray had hoped that the painter and friend Hallward could save him ever, but the time when Hallward found the secret between the picture and Gray was too late to save him. At that time, though shocked by the evil done by Gray, Hallward still did not give up the rescue of Gray and hoped that Gray could pray and repent in front of the picture. He said, "It is never too late, Dorian. Let us kneel down and try if we cannot remember a prayer. Isn't there a verse somewhere, 'Though your sin be as scarlet, yet I will make them as white as snow'?" (Wilde, 2014, p. 152). However, it was too late for Gray and he lost his control of ration and obeyed to his instinct to kill Hallward. After killing the painter, though Gray was shocked by the horrific changes of the picture and did not dare to look the distorted faces and bloody hands in the picture. Because of great fear to the changes of his own soul and the instinct of keep youth, Gary chose to go on hiding his human factor and give up the rescue of his own soul. 
At that time, however, Gray had been warned by the great changes of the picture and constrained by the picture and also had the thought to be good and constrain himself. He had thought himself like "the painting of a sorrow, and a face without a heart" (Wilde, 2014, p. 208). Then when he even let off the girl Hetty Merton falling in love with him, the human factor had beaten the animal factor. What is more, because of the portrait witnessing his sins is the good of his human nature, the behavior of stabbing the portrait is actually a behavior of suicide. Nevertheless, combined in a whole, both of human factor and animal factor cannot exist when losing each other side. So when taking the sword to stab the picture, Gray fell down to the ground and died.

The picture represents the human factor, and bears all evil done by Gray in reality, while Gray obeys the unruly animal factor to spend his youth indulging in pleasure without leaving any moral stain on his face. However, though Gray enjoys the life, he still lives in the fear that his secret is found all the time. The picture, the human factor of Gray, guides and constrains his irrational behaviors to struggle with the animal factor. In the end, the animal factor was beaten by the human factor, and Gray could not bear the great moral burdens, so he stabbed the picture and himself to bear the ethical responsibility that should be bore by himself. "The tragedy of Dorian Gray also exemplifies Wilde's witty subversion of tradition mimetic theory” (LIU, 2008, p. 312).

Gray originally wanted to split the human factor out of sphinx factor to let animal factor free and capricious, but according to the struggles between the human factor and the animal factor during more than 10 years, the animal factor was constrained by human factor and the human factor won in the end. When the human factor completely holds the dominant position, it is the time for Gray to die, because though Gray wants to kill the dirty soul and animal factor of his, it cannot be true that human factor or animal factor control a man completely without each other side. "This novel is symbolic of his art theory" (GAO, 2004, p. 135).

\section{Conclusion}

The Picture of Dorian Gray is "a novel full of vivid description of the depraved life, heinous crime and divided personality of a young hedonist" (LIU, 2004, p. 448). The human factor and the animal factor of Dorian Gray are especially unique. The writer Oscar Wilde creatively divides the sphinx factor, Dorian Gray, into the human factor, the picture bearing all sins and desires, and the animal factor, Gray who makes deal with the devil. Several changes of the picture present not only the process that the human factor guides and controls the animal factor, but also the struggles between the human factor and the animal factor, which pushes forward the developments of the story. It shows that man will commit crime under the control of the animal factor, and will self-rescue for the guidance of the human factor. And the suicide behavior of Gray in the end shows that after chosen by ethics, rational will is possible to beat free will and irrational will, that is to say, the human factor is a senior existence to the animal factor and able to beat the animal factor. But the animal factor cannot be beaten completely, or it is the end of man. It is good for us. On the one hand, we can make ethical criticism on literature when we meet a novel one day in the future. On the other hand, we can know that each of us is a sphinx factor with the human factor and the animal factor. What is more, we will have both of animal instincts of animal factor and goodness of human factor and we should balance them. At the same time, we had better make our human factors overweigh and control our animal factors so that we will be better men and will not degrade. 


\section{References}

GAO, J. H. (2004). A short history of British novel. Kaifeng: Henan University Press.

LIU, B. S. (2004). A short history of English literature. Zhengzhou: Henan People's Publish House.

LIU, X. M. (2013). On "Sphinx Factor" and literary teaching and literary teaching: A case study of four classic novels. Wuhan: Central China Normal University Press.

LIU, Y. Q. (2008). A brief history of English literature -From the old English period to the 1990s. Beijing: Foreign Language Teaching and Research Press.

NIE, Z. K. (2011). Ethical literary criticism: Ethical choice and sphinx factor. Foreign Literature Studies, 33(6), 1-13.

Wilde, O. (2014). The picture of Dorian Gray. Nanjing: Yilin Press. 